\title{
Catch-up growth up to ten years of age in children born very preterm or with very low birth weight
} Noël BB Knops ${ }^{\dagger 1}$, Kommer CA Sneeuw ${ }^{\dagger 2}$, Ronald Brand ${ }^{3}$, Elysee TM Hille ${ }^{2}$, A Lya den Ouden ${ }^{2}$, Jan-Maarten Wit ${ }^{* 1}$ and S Pauline Verloove-Vanhorick ${ }^{1,2}$

Address: ${ }^{1}$ Department of Paediatrics; Leiden University Medical Center, J6S; P.O. Box 2600; 2300 RC Leiden; The Netherlands, ${ }^{2 T N O}$ Prevention and Health, Child Health Division, Leiden; The Netherlands and ${ }^{3}$ Department of Medical Statistics, Leiden University Medical Center; The Netherlands

Email: Noël BB Knops - n.knops@planet.nl; Kommer CA Sneeuw - ksneeuw@velsen.nl; Ronald Brand - R.Brand@lumc.nl; ElyseeTM Hille - et.hille@pg.tno.nl; A Lya den Ouden - l.denouden@pg.tno.nl; Jan-Maarten Wit* - J.M.Wit@lumc.nl; S Pauline VerlooveVanhorick - SP.Verloove@pg.tno.nl

* Corresponding author †Equal contributors

Published: 20 July 2005

BMC Pediatrics 2005, 5:26 doi:10.1186/147|-2431-5-26
Received: 22 January 2005

Accepted: 20 July 2005

This article is available from: http://www.biomedcentral.com/I47I-243I/5/26

(C) 2005 Knops et al; licensee BioMed Central Ltd.

This is an Open Access article distributed under the terms of the Creative Commons Attribution License (http://creativecommons.org/licenses/by/2.0), which permits unrestricted use, distribution, and reproduction in any medium, provided the original work is properly cited.

\begin{abstract}
Background: Improved survival due to advances in neonatal care has brought issues such as postnatal growth and development more to the focus of our attention. Most studies report stunting in children born very preterm and/or small for gestational age. In this article we study the growth pattern of these children and aim to identify factors associated with postnatal catch-up growth.

Methods: 1338 children born with a gestational age $<32$ weeks and/or a birth weight of $<1500$ grams were followed during a Dutch nationwide prospective study (POPS). Subgroups were classified as appropriate for gestational age and $<32$ weeks (AGA) or small for gestational age $(<32$ wks SGA and $\geq 32$ wks SGA). Data were collected at different intervals from birth until 10 years for the 962 survivors and compared to reference values. The correlation between several factors and growth was analysed.

Results: At 10 years the AGA children had attained normal height, whereas the SGA group demonstrated stunting, even after correction for target height (AGA: 0.0 SDS; SGA <32 wks: 0.29 SDS and $\geq 32$ wks: -0. I ISDS). Catch-up growth was especially seen in the SGA children with a fast initial weight gain. BMI was approximately I SD below the population reference mean.

Conclusion: At 10 years of age, children born very preterm AGA show no stunting. However, many children born SGA, especially the very preterm, show persistent stunting. Early weight gain seems an important prognostic factor in predicting childhood growth.
\end{abstract}

\section{Background}

Advances in neonatal care in the past two decades have improved survival of very preterm and low birth weight infants dramatically. This has brought issues such as developmental outcome and growth of these 'survivors' to the focus of our attention [1]. In 1989 Barker et al demonstrated an increase in mortality from coronary heart disease in adulthood in subjects who had low birth weight [2], and this observation was followed by studies of many others on long term adverse effects of intra-uterine growth 
retardation [3]. Furthermore not only the appropriateness of weight for gestational age but the course of postnatal growth seems to predict later neurodevelopmental outcome in children with low birthweight [4]. Follow-up of these children is an important tool in learning to understand and tackling problems that can occur.

Several studies have studied physical growth during early childhood in children born preterm, small for gestational age (SGA) or appropriate for gestational age (AGA). They show stunting for all groups with limited to no catch-up growth especially in SGA group [5-11]. This could not be explained by factors known to influence postnatal growth such as: hospitalisation, interventional status, bronchopulmonary dysplasia, socio-economic status, parental level of education, neonatal thyroxine or thyroxine stimulating hormone levels $[8,12]$.

Most data reporting on further growth into adolescence show incomplete catch up growth and therefore persistent stunting, especially in those born SGA [13-16]. Those who report attainment of normal height studied mainly children born AGA $[17,18]$. Only the female SGA cohort followed by Hack et al reached normal adult height but their male counterparts did not [19]. Thus stunting is primarily seen in the infant with low birth weight for gestational age. These findings suggest a long-term relationship between intrauterine growth retardation and growth into adolescence. Determining the factors that cause growth impairment in these children may enable us to find therapeutic or preventive options.

Following an earlier report on height achievement at five years of a large cohort of children born very preterm or VLBW [12], we studied the growth pattern up to 10 years of age in the same children. The data were collected in a nationwide effort of Dutch pediatricians: the " Project On Preterm and Small for Gestational Age Infants in The Netherlands" (POPS) [20]. We aimed to identify factors associated with catch-up growth between 5 and 10 years of age. Predictive values and sensitivity rates of short stature at younger age for having short stature at 10 years of age were determined. Finally, Body Mass Index was calculated to assess nutritional status in our study population.

\section{Methods}

The POPS study was started in 1983 to investigate relationships between perinatal factors, mortality and morbidity in very preterm and VLBW infants. The protocol was approved by the medical ethics committees of the participating hospitals and parents gave informed consent. The study population consisted of live-born infants in The Netherlands from January 1 to December 31, 1983, with a gestational age of $<32$ weeks and / or a birth weight of $<1500$ g. Follow-up examinations were performed at the approximate corrected ages of: 3, 6, 12 and 24 months and again at the approximate chronological age of 5 and 10 years. Of the original 1338 children, 962 were alive at 10 years of age.

Paediatricians performed length/height measurements at 3 and 6 months and at 1,2 and 5 years. At 10 years, the parents reported height as part of an extensive questionnaire. Recent growth curves were used as reference values for body length/height measurements and body mass index $[21,22]$. These measurements were collected in 1996-1997 during a nationwide growth study on individuals of Dutch origin aged 0 to 21 years. Based on these reference values, for each child the standard deviation score (SDS) was calculated using corrected age (height minus age/sex-specific mean height in the reference population divided by age/sex-specific SD in the reference population). A child was considered having "short stature" at a specific age if his/her height was below the 10th percentile (being equivalent to approximately -1.3 SDS) of the reference population.

Since in our earlier report [12] reference values were obtained from the Dutch growth curves of 1980 [23], the SD-scores employed in the current study were also compared to those based on the 1980 reference data. Only marginal differences were observed, with the SD-scores based on the 1996-1997 reference values being on average 0.04 SD lower than those based on the 1980 reference data (range -0.37 to 0.34 ).

Classification of AGA/SGA (appropriate/small-for-gestational-age) infants was based on measurements of birth weight relative to gestational age, described by Kloosterman $[24,25]$. An SGA infant has a birth weight less than the 10th percentile for gestational age, gender and parity.

For the present study, non-Caucasian children and children with congenital malformations were excluded, since the reference data cannot be used for these children. Hence, 753 of the 962 surviving children were included in the analysis.

Statistical analyses included the following steps. The growth pattern of the children over time was examined by comparing mean length/height SDS, median percentiles and percentages of children below the 10th percentile $(<\mathrm{P} 10)$ at the various ages. Considering possible bias due to differences in genetic growth potential, target height (TH) was calculated for each individual using parental height data compared to Dutch national growth statistics. Target height was defined as the mean of parental height corrected for the mean difference in height between sexes, plus the mean increase in height per generation (according to Dutch reference values [23]:((height father + height 
Table I: Clinical characteristics of the different subgroups according to gestational age and weight of the entire study population, of the group lost to follow up at age 10 years and of the children with available data on weight increase during the first three months.

\begin{tabular}{|c|c|c|c|c|c|c|c|c|c|}
\hline & $\mathrm{n}$ & (\% males) & $\begin{array}{l}\text { Mean } \\
\text { Gestational } \\
\text { Age } \\
\text { (wk) }\end{array}$ & $\begin{array}{l}\text { Mean Birth- } \\
\text { weight } \\
\text { (gram) }\end{array}$ & $\begin{array}{c}\text { Multiple } \\
\text { Birth } \\
(\%)\end{array}$ & $\begin{array}{c}\text { Respiratory } \\
\text { support }>1 \\
\text { week } \\
(\%)\end{array}$ & $\begin{array}{c}\text { Intra Cranial } \\
\text { Haemorrha } \\
\text { ge } \\
(\%)\end{array}$ & $\begin{array}{c}\text { Necrotising } \\
\text { Entero } \\
\text { Colitis } \\
\text { (\%) }\end{array}$ & $\begin{array}{l}\text { Mean } \\
\text { Hospital } \\
\text { stay } \\
\text { days }\end{array}$ \\
\hline $\begin{array}{l}<32 \text { wks/ } \\
\text { AGA }\end{array}$ & 445 & 53.1 & 29.7 & 1412 & 26.7 & 27.8 & 21.7 & 4.5 & 64 \\
\hline $\begin{array}{l}<32 \text { wks/ } \\
\text { SGA }\end{array}$ & 86 & 51.2 & 30.3 & 968 & 11.6 & 23.3 & 14.0 & 8.1 & 86 \\
\hline $\begin{array}{l}\geq 32 \text { wks/ } \\
\text { SGA }\end{array}$ & 222 & 49.5 & 34.5 & 1278 & 16.7 & 2.5 & 5.1 & 5.6 & 59 \\
\hline \multicolumn{10}{|c|}{ Lost to follow up at age 10 years } \\
\hline & 243 & 49.2 & 31.1 & 1326 & 23.0 & 18.4 & 18.3 & 5.8 & 63 \\
\hline \multicolumn{10}{|c|}{ Weight Increase at 3 months } \\
\hline$<3500 \mathrm{gr}$ & 257 & 45.3 & 32.1 & 1275 & 21.7 & 20.6 & 14.9 & 6.2 & 69 \\
\hline$\geq 3500 \mathrm{gr}$ & 389 & 54.6 & 30.1 & 1349 & 21.2 & 19.3 & 16.3 & 4.6 & 62 \\
\hline
\end{tabular}

mother plus or minus $12 \mathrm{~cm}$ ) divided by $2+3 \mathrm{~cm}$ ). Using individual target height, target height SD-scores (TH-SDS) and height SDS corrected for TH (HSDS $_{\text {corr }}$ ) were assessed (TH-SDS: (TH minus mean adult height (male or female)) divided by the sex-specific standard deviation for adult height) and HSDS $_{\text {corr }}$ : height-SDS minus TH-SDS). Separate analysis of growth patterns was performed among three subgroups of children: very preterm but appropriate-for-gestational age ( $<32$ wks/AGA), very preterm and small-for-gestational age ( $<32 \mathrm{wks} / \mathrm{SGA})$ and gestational age of 32 weeks or over who were small-for-gestational age ( $\geq 32$ wks/SGA). The clinical characteristics of these subgroups are shown in table 1 . The relationship between several factors and catch-up growth between 5 and 10 years of age was explored by means of regression analysis. Differences between the 5- and 10-years height SDS were calculated and compared between the three defined subgroups, as well as for single/multiple birth, sex, socio-economic status, maternal and paternal height. Crosstabulations were used to examine the predictive values and sensitivity rates of height $<\mathrm{P} 10$ (and $<\mathrm{P} 3$ ) at various ages for height $<\mathrm{P} 10$ (and $<\mathrm{P} 3$ ) at 10 years of age. Followup data on weight were used to study the effect of early postnatal growth on height at 10 years and to assess BMI.

\section{Results}

Of the 753 children in the POPS cohort who met our selection criteria, length/height measurements were available for 649 to 721 children at various ages up to 5 years of age ( $86 \%$ to $96 \%$ ). Table 1 shows the clinical characteristics of the survivors according to subgroup. At 10 years, height data were obtained for 510 children (68\%).

Table 2 shows the mean length/height data expressed as SDS, median percentiles and proportions of children
$<\mathrm{P} 10$ for the total and subgroups. In the total group there was a substantial increase in mean SDS from -1.28 at 3 months to -0.18 at 10 years of age, similarly reflected in an increase in median percentile and decrease in percentage of children $<\mathrm{P} 10$. Both the median percentile and the percentage $<\mathrm{P} 10$ at 10 years are similar to those at 5 years of age. The $17 \%$ of children $<\mathrm{P} 10$ at 10 years of age were on average $13 \mathrm{~cm}$ shorter (range 8 to $25 \mathrm{~cm}$ ) than sex/agespecific reference values $(131 \mathrm{~cm}$ versus $144 \mathrm{~cm})$.

To examine whether the missing data pattern at 10 years was random or not, mean SD-scores at 5 years $(n=721)$ were compared between the 508 children for whom height measurements were available at both 5 and 10 years and the 213 children without a 10-years height measurement. A statistically significant difference was noted $(p=0.02)$, with mean SD-scores of -0.18 and -0.63 for those with and without 10 -years data, respectively. To adjust for possible bias due to drop-out of shorter children, SD-scores for the 213 children without height measurements at 10 years but for whom height at 5 years was available were estimated by means of a linear regression equation. This equation was based on regression of 10years SDS on those at 5 years in the subgroup of 508 children with both measurements available: 10-years SDS = $0.006+(0.832 \times 5$-years $\mathrm{SDS})$; explained variance $R^{2}=$ 0.58 . As shown in Table 2 , this calculation yielded a mean height SDS of -0.24 (instead of -0.18 for available measurements).

For the $<32$ wks/AGA children moderate stunting was noted with catch-up growth up to 5 years of age but none between age 5 and 10 years. For both the $<32$ wks/SGA and the $\geq 32$ wks/SGA children, more serious stunting was noted with continuing catch-up growth up to 10 years. 
Table 2: Growth measurements uncorrected and corrected for target height $\left(\right.$ HSDS $\left._{\text {corr }}\right)$ at various ages for subgroups based on weight for gestational age

\begin{tabular}{|c|c|c|c|c|c|}
\hline \multirow[b]{2}{*}{ Approximate age } & \multicolumn{2}{|c|}{ Length/height-SDS } & \multirow{2}{*}{$\begin{array}{c}\text { Percentiles } \\
\quad<\text { PIO }\end{array}$} & \multicolumn{2}{|c|}{ HSDS $_{\text {corr }}$} \\
\hline & $n$ & mean & & $n$ & SDS \\
\hline \multicolumn{6}{|l|}{ Total group } \\
\hline 3 months & 659 & -1.28 & $48 \%$ & 633 & -1.11 \\
\hline 6 months & 649 & -0.95 & $39 \%$ & 626 & -0.76 \\
\hline I year & 670 & -0.76 & $32 \%$ & 649 & -0.58 \\
\hline 2 years & 651 & -0.64 & $28 \%$ & 628 & -0.44 \\
\hline 5 years & 721 & -0.18 & $18 \%$ & 719 & 0.03 \\
\hline 10 years (observed) 1 & 510 & -0.18 & $17 \%$ & 509 & -0.07 \\
\hline 10 years (estimated) ${ }^{2}$ & 723 & -0.24 & $17 \%$ & 721 & -0.09 \\
\hline \multicolumn{6}{|l|}{$<32$ wks/AGA } \\
\hline 3 months & 388 & -0.68 & $29 \%$ & 381 & -0.58 \\
\hline 6 months & 383 & -0.49 & $24 \%$ & 382 & -0.39 \\
\hline I year & 387 & -0.43 & $22 \%$ & 386 & -0.34 \\
\hline 2 years & 378 & -0.33 & $20 \%$ & 374 & -0.21 \\
\hline 5 years & 422 & 0.11 & $7 \%$ & 420 & 0.18 \\
\hline 10 years (observed)। & 298 & -0.04 & $15 \%$ & 298 & 0.00 \\
\hline 10 years (estimated) ${ }^{2}$ & 423 & -0.06 & $15 \%$ & 422 & 0.01 \\
\hline \multicolumn{6}{|l|}{$\leq 32 \mathrm{wks} / \mathrm{SGA}$} \\
\hline 3 months & 78 & -2.22 & $82 \%$ & 78 & -1.90 \\
\hline 6 months & 72 & -1.72 & $64 \%$ & 72 & -1.39 \\
\hline I year & 78 & -1.38 & $46 \%$ & 78 & -1.08 \\
\hline 2 years & 78 & -1.33 & $45 \%$ & 78 & -1.02 \\
\hline 5 years & 85 & -0.65 & $24 \%$ & 85 & -0.37 \\
\hline 10 years (observed)। & 64 & -0.55 & $25 \%$ & 64 & -0.29 \\
\hline 10 years (estimated) ${ }^{2}$ & 85 & -0.64 & $24 \%$ & 85 & -0.33 \\
\hline \multicolumn{6}{|l|}{$\geqq 32 \mathrm{wks} / \mathrm{SGA}$} \\
\hline 3 months & 193 & -2.19 & $78 \%$ & 174 & -1.90 \\
\hline 6 months & 194 & -1.60 & $72 \%$ & 172 & -1.31 \\
\hline I year & 205 & -1.16 & $48 \%$ & 185 & -0.87 \\
\hline 2 years & 195 & -0.95 & $36 \%$ & 176 & -0.67 \\
\hline 5 years & 214 & -0.62 & $25 \%$ & 214 & -0.35 \\
\hline 10 years (observed)। & 148 & -0.35 & $17 \%$ & 147 & -0.13 \\
\hline 10 years (estimated) ${ }^{2}$ & 215 & -0.48 & $16 \%$ & 214 & -0.20 \\
\hline
\end{tabular}

I observed length for availabe cases

2 observed length for availabe cases + estimated length (based on length at 5 years) for missing cases

The $<32$ wks/AGA group had a normal target height $(-0.01$ SDS). However, both subgroups born SGA had lower target height of -0.29 SDS. Therefore, in the SGA group length/height-SDS corrected for TH (HSDS ${ }_{\text {corr }}$ ) is substantially higher than uncorrected length/height-SDS (mean difference HSDS $_{\text {corr }}$ - length/height-SDS: + 0.30 SDS in the $<32$ weeks and +0.27 SDS in the $\geq 32$ weeks group). Correction in the $<32$ wks/AGA group was small (mean difference: +0.10 SDS).

The relationship between several other factors and catchup growth between 5 and 10 years of age was examined among those children for whom height measurements were available at both ages. The change between the 5and 10-years SD-scores for height was on average 0.07 SDS, a large range was noted at the individual level (-2.96 to 3.74). Although parental height and, to a smaller extent, multiple birth and socio-economic status were significantly associated with height at 5 and 10 years, these factors were not associated with catch-up growth in that period (respectively $\mathrm{p}=0.14$ for multiple birth and $\mathrm{p}=0.3$ for socio-economic status). Regression analysis showed that, in addition to the observed differences in catch-up growth between the three subgroups $(p=0.001)$, the level of catch-up growth was independently associated with sex $(p=0.03)$. Table 3 shows that more catch-up growth was 
Table 3: Comparison of growth patterns in boys and girls in the different subgroups

\begin{tabular}{|c|c|c|c|c|c|c|}
\hline & \multirow[b]{2}{*}{$n$} & \multicolumn{3}{|c|}{ Mean length/height SD-scores } & \multicolumn{2}{|c|}{ Proportions < PIO } \\
\hline & & $5 \mathrm{yr}$ & $10 \mathrm{yr}$ & change & $5 \mathrm{yr}$ & $10 \mathrm{yr}$ \\
\hline \multicolumn{7}{|c|}{$\leq 32 \mathrm{wks} / \mathrm{AGA}$} \\
\hline girls & 133 & -0.05 & -0.15 & -0.10 & $9 \%$ & $14 \%$ \\
\hline boys & 164 & -0.24 & -0.21 & 0.03 & $17 \%$ & $20 \%$ \\
\hline \multicolumn{7}{|c|}{$\leq 32 \mathrm{wks} / \mathrm{SGA}$} \\
\hline girls & 31 & -0.57 & -0.50 & 0.07 & $19 \%$ & $26 \%$ \\
\hline boys & 33 & -1.14 & -0.89 & 0.25 & $49 \%$ & $36 \%$ \\
\hline \multicolumn{7}{|c|}{$\geqq 32 \mathrm{wks} / \mathrm{SGA}$} \\
\hline girls & 66 & -0.69 & -0.52 & 0.17 & $21 \%$ & $24 \%$ \\
\hline boys & 63 & -0.72 & -0.35 & 0.37 & $25 \%$ & $19 \%$ \\
\hline
\end{tabular}

Table 4: Relation between short stature at age 5 and 10 years

\begin{tabular}{|c|c|c|c|}
\hline & \multirow[t]{2}{*}{$\mathrm{n}$} & \multicolumn{2}{|c|}{ At 10 years } \\
\hline & & $<P I 0$ & $\geq P I 0$ \\
\hline \multicolumn{4}{|c|}{ At 5 years } \\
\hline$<P 10$ & 95 & 66 (69\%) & $29(31 \%)^{*}$ \\
\hline \multirow[t]{2}{*}{$\geq \mathrm{PIO}$} & 413 & 37 (9\%) & 376 (9|\%) \\
\hline & & $<\mathrm{P} 3$ & $\geq \mathrm{P} 3$ \\
\hline \multicolumn{4}{|c|}{ At 5 years } \\
\hline$<\mathrm{P} 3$ & 44 & 29 (66\%) & $15(34 \%) \dagger$ \\
\hline$\geq \mathrm{P} 3$ & 464 & $18(4 \%)$ & 446 (96\%) \\
\hline
\end{tabular}

* median percentile: 23 ( 16 children < P25)

† median percentile: 14 ( 12 children $<$ P25)

observed for boys than for girls. Regarding the different subgroups, more substantial catch-up growth was observed for the SGA boys, especially for those of $\geq 32$ weeks (mean SD-score change of 0.37 ). Only marginal changes in 5- and 10-years mean SD-scores were seen for girls in all three subgroups, as well as for the $<32$ wks/AGA boys. In these children, the percentage of children $<\mathrm{P} 10$ at 10 years of age were even slightly higher than at 5 years of age. The highest percentage $<\mathrm{P} 10$ at 10 years of age was observed for $<32 \mathrm{wks} / \mathrm{SGA}$ boys, in spite of a significant decrease in the last 5 years (from $49 \%$ to $36 \%$ ).

The predictive value of height $<\mathrm{P} 10$ at various ages for height $<\mathrm{P} 10$ at 10 years was examined by cross-tabulation of available measurements. The predictive value at 5 years of age was $69 \%$ (Table 4 ). Lowering the cut-off point from P10 to P3, a stricter criterion for "short stature", did not increase the predictive value.
To examine the effect of early postnatal growth on height at 10 years we looked at the average increase in weight during the first three months, approximately 3500 grams, and used this as a cut-off point defining two subgroups (fast and slow initial growth rate). Clinical characteristics and HSDS ${ }_{\text {corr }}$ for these groups are given in table 1 and 5, respectively. Children with fast initial growth already attained normal height for TH SDS at 5 years, while those with slow initial growth showed persistent stunting. The fast subgroup of $<32$ wks/AGA attained full catch-up growth at 2 years of age. The fast subgroup of the $\geq 32 /$ SGA weeks did so at age 5 year. All slow equivalents show persistent stunting. Despite initial high catch-up growth in the fast subgroup of the very preterm SGA they remain stunted at age 10 years.

Body Mass Index (BMI) and BMI-SDS for the total group and different subgroups was calculated. BMI for all the children was approximately $1 \mathrm{~kg} / \mathrm{m} 2$ below Dutch refer- 
Table 5: Height corrected for target height $\left(\right.$ HSDS $\left._{\text {corr }}\right)$ in children with fast and slow initial growth for the different subgroups based on weight for gestational age.

\begin{tabular}{|c|c|c|c|c|}
\hline \multirow[b]{3}{*}{ Approximate age } & \multirow{2}{*}{\multicolumn{3}{|c|}{$\begin{array}{c}\text { HSDS }_{\text {corr }} \\
\text { Weight increase at } 3 \text { months }\end{array}$}} & \multirow[b]{3}{*}{ mean } \\
\hline & & & & \\
\hline & $n$ & mean & $n$ & \\
\hline \multicolumn{5}{|l|}{ Total group } \\
\hline 3 months & 257 & -1.85 & 389 & -0.59 \\
\hline 6 months & 252 & $-1.4 \mid$ & 371 & -0.32 \\
\hline I year & 263 & -0.99 & 370 & -0.27 \\
\hline 2 years & 243 & -0.85 & 367 & -0.18 \\
\hline 5 years & $27 I$ & -0.61 & 391 & -0.08 \\
\hline 10 years (observed) & 189 & -0.37 & 282 & -0.08 \\
\hline 10 years (estimated) & 270 & -0.42 & 392 & -0.08 \\
\hline \multicolumn{5}{|l|}{$<32 \mathrm{wks} / \mathrm{AGA}$} \\
\hline 3 months & 100 & -1.29 & 278 & -0.32 \\
\hline 6 months & 101 & -1.05 & 263 & -0.14 \\
\hline I year & 104 & -0.75 & 262 & -0.19 \\
\hline 2 years & 98 & -0.65 & 258 & -0.08 \\
\hline 5 years & 108 & -0.41 & 278 & -0.04 \\
\hline 10 years (observed) & 77 & -0.35 & 199 & -0.07 \\
\hline 10 years (estimated) & 109 & -0.33 & 279 & -0.07 \\
\hline \multicolumn{5}{|l|}{$<32 \mathrm{wks} / \mathrm{SGA}$} \\
\hline 3 months & 37 & -2.47 & 41 & -1.38 \\
\hline 6 months & 34 & -2.03 & 37 & -0.82 \\
\hline I year & 38 & -1.36 & 38 & -0.81 \\
\hline 2 years & 38 & -1.34 & 38 & -0.64 \\
\hline 5 years & 41 & -0.91 & 41 & -0.37 \\
\hline 10 years (observed) & 29 & -0.46 & 32 & -0.37 \\
\hline 10 years (estimated) & 41 & -0.60 & 41 & -0.33 \\
\hline \multicolumn{5}{|l|}{$\geqq 32 \mathrm{wks} / \mathrm{SGA}$} \\
\hline 3 months & 120 & -2.20 & 70 & -1.30 \\
\hline 6 months & 117 & -1.57 & 71 & -0.78 \\
\hline I year & 121 & -1.11 & 70 & -0.31 \\
\hline 2 years & 107 & -0.85 & 71 & -0.28 \\
\hline 5 years & 122 & -0.73 & 72 & -0.06 \\
\hline 10 years (observed) & 83 & -0.38 & 51 & -0.06 \\
\hline 10 years (estimated) & 120 & -0.44 & 72 & -0.04 \\
\hline
\end{tabular}

ence values [22]. However, the overall trend is similar to Dutch reference values. Mean BMI-SDS in the total group was -0.73 at 10 years. The SGA group had the lowest BMI (mean BMI-SDS: -1.02 and -0.96 for the $<32$ weeks and $\geq 32$ weeks, respectively). The $<32$ wks/AGA had the highest BMI (-0.56 SDS). BMI-SDS was lower in early childhood in both the SGA and AGA group.

\section{Discussion}

Our results demonstrate, despite catch-up growth, persistent stunting until the age of 10 year in children born SGA, both before and after 32 weeks. The $<32$ wks/AGA showed little to no stunting and no catch-up growth from 5 to 10 yr. The improvement of SDS does not necessarily implicate a decrease in the absolute difference of a subject's height versus the average for age so that catch-up growth can remain unnoticed for the families. We are aware that the reporting by the parents of their child's height at 10 yrs could be imprecise, however this will be the same for all groups and have therefore no effect on the final conclusion of this study. Correction for Target Height suggests that the low height SDS in SGA children is partially associated with genetic factors. Failing to correct for target height leads to an overestimating of stunting in especially the SGA children $( \pm 0.3$ SDS $)$. This point was also made by Ford et al [26]. These data show that intrauterine growth retardation has more important long-term impact on growth than gestational age, suggesting an 
intrinsic lesser growth potential in children born small for date or a persistent effect of growth retardation in utero. A study by Sung et al showed more stunting in the SGA at 4 yr. compared to weight matched children born AGA (mean gestational age: SGA: 29 wk; AGA $26 \mathrm{wk}$ ) although the latter had more complications in early infancy [10]. Peralta-Carcelen et al demonstrated persistent stunting in adolescence in extremely low birth weight children without major handicaps [16]. Also in our study there was no significant difference in the incidence of neonatal morbidity between the subgroups (data published earlier [27]). Further analysis of the extent of each complication as stated in table 1 was not performed in this study but could be important for growth in individual cases (for example gut resection after NEC). Thus, intrauterine growth retardation seems a more important factor in determining childhood growth than neonatal complications associated with long-term physical and mental impairments.

Early recognition of persistent stunting can be of value for better treatment and preventive measures. In our study the predictive value of height $<\mathrm{P} 10$ at various ages for height at 10 years increased with age until $69 \%$ at 5 years. Lowering the cut-off point to $<\mathrm{P} 3$ did not improve the predictive value much, probably because of continuing catch-up growth. If in the future these cut-off points are used as a criterion to start growth enhancing treatment at an age of 5 years, the results of treatment should be compared with these figures on spontaneous growth.

Early postnatal (catch-up) growth possibly provides a useful tool for predicting height at 10 years. Because of difficulty in the accurate measurement of length at birth we did not register length at birth in our study and expressed early catch-up growth in weight gain. The arbitrary cut-off point we chose of the mean weight increase in the first 3 months (approximately 3500 grams) could result in wrongfully selecting children to a group with a different growth potential compared to their own. This would result in pulling height outcome of the different groups toward each other (regression to the mean). However our data show a clear difference between the subgroups, supporting the possibility of an inherently different growth potential. Children with an initial high catch-up growth generally attain normal height but the slow starters and the very preterm SGA do not. A similar observation was made by others $[28,29]$. Fewtrell et al suggested a distinction in children with an intrinsic or extrinsic disturbed intra-uterine growth potential after the observation that preterm children whose mothers had hypertension or toxemia showed more catch-up growth and less stunting at 12 year compared to those whose mothers were unaffected [30].
Variation in early catch-up could be caused by a disturbance in hormonal response. Albertsson-Wikland et al demonstrated low growth hormone, IGF-I, IGFBP-3 and leptin secretion in the subgroup of term SGA children with little catch-up growth at two months and short final height versus term SGA children with good catch-up and no stunting [31]. This could be due to rare IGF-I polymorphisms more frequently seen in the SGA and is associated with low bone mineral density [32]. This again could be a possible explanation for the high alkaline phosphatase levels in especially SGA preterm infants who remain short at age $12 \mathrm{yr}$, demonstrated by Fewtrell et al who suggested early metabolic bone disease as a cause for stunting in these children [30].

Preterm boys demonstrated more stunting at age 5 and 10 yr. but also showed more catch-up growth than girls. Only the $\geq 32$ wks/SGA boys demonstrated less stunting than the girls at age 10 years. Other studies also demonstrated more stunting in SGA boys [19,33]. Possible explanations for the higher catch-up growth in boys in our study include a higher degree of stunting compared to the girls (which leaves them more to catch-up), a higher morbidity in the neonatal period and later life, and a different time of onset of puberty. Girls born SGA were shown to have an exaggerated adrenarche by Ibanez et al [34,35] but no difference has been demonstrated in the onset of puberty between very preterm SGA and a control population $[14,26,36]$. Nonetheless an advanced bone age has been reported despite similar sexual maturation in adolescents of very preterm SGA origin [16,37]. Advanced bone age could further compromise final height in these children. Unfortunately, we have no data on sexual maturity in our population.

Our study population demonstrated a low mean BMI compared to their peers. However at age 10 years there was a slight increase in BMI-SDS in relation to the previous ages. Although BMI-SDS is lowest in the SGA, a similar trend is observed in all groups. Saigal et al [14] demonstrated a 1.9 SD lower BMI in their very preterm/ SGA group vs. controls at age 8 . At adolescence there remained a difference of $-1.5 \mathrm{SD}$ in BMI. A cohort study from the United States performed by Hack et al showed eventual normal adult BMI in SGA girls (0.4 SDS) but not in boys (-0.3 SDS) [19]. Hediger et al demonstrated lower mid-upper arm circumference in SGA children (-0.5 SDS) [38]. These data suggest a diminished nutritional status again especially in the SGA group when compared to their peers. This does not necessarily implicate a higher incidence of wasting in the study population but could also be explained by the increased incidence of obesity in the Dutch children and higher BMI reference values of 1997 compared to 1980. 


\section{Conclusion}

In this study we show that children born very preterm with an appropriate weight for gestational age show little or no stunting at the age of $10 \mathrm{yr}$. However children born small for gestational age, especially those born <32 weeks, show persistent stunting at age $10 \mathrm{yr}$ notwithstanding considerable catch-up growth in many of them. Early weight gain seems an important factor in predicting catchup growth. Knowledge about spontaneous growth is useful if one considers offering growth-enhancing treatment to low birth weight children with short stature in early childhood.

\section{List of abbreviations \\ SGA Small for Gestational Age}

\section{AGA Appropriate for Gestational Age}

\section{SDS Standard Deviation Score}

TH Target Height

HSDS $_{\text {corr }}$ Height corrected for Target Height

BMI Body Mass Index

\section{Competing interests}

The author(s) declare that they have no competing interests.

\section{Authors' contributions}

$\mathrm{NK}$ and KS were involved in the design of the analysis and in writing the manuscript. $\mathrm{RB}$ performed the statistical analyses. EH and LdO provided the data of the POPS cohort. JMW supervised the design and writing process. SVV is projectleader of POPS. All authors contributed to the preparation of the manuscript.

\section{Acknowledgements}

We thank all the children and parents for their friendly cooperation and all the contributing pediatricians for their kind help in the data collection.

\section{References}

I. Hack M, Flannery D, Schluchter M, Cartar L, Borawski E, Klein N: Outcomes in young adulthood for very-low-birth-weight infants. NEJM 2002, 346:149-157.

2. Barker D, Osmond C, Winter P, Margretts B, Simmonds S: Weight in infancy and death from ischaemic heart disease. Lancet 1989, 2:577-580.

3. Jaquet $D$, Czernichow P: Born Small for Gestational Age: Increased Risk of Type 2 Diabetes, Hypertension and Hyperlipidaemia in Adulthood. Hormone Research 2003, 59(suppl I): $131-137$

4. Latal-Hajnal B, von Siebenthal K, Kovari H, Bucher H, Largo R: Postnatal Growth in VLBW Infants: Significant Association with Neurodevelopmental Outcome. J Pediatr 2003, I 43:163-170.

5. Sann L, Darre E, Lasne Y, Bourgeois J, Bethenod M: Effects on prematurity and dysmaturity on growth at age 5 years. J Pediatr 1986, $109(4): 681-686$.
6. Casey P, Kraemer H, Bernbaum J, Yogman M, Sells J: Growth status and growth rates of a varied sample of low birth weight, preterm infants: A longitudinal cohort from birth to three years of age. J Pediatr 1991, I 19:599-605.

7. Casey P, Kraemer H, Bernbaum J, Tyson J, Sells J, Yogman M, Bauer C: Growth patterns of low birth weight preterm infants: A longitudinal analysis of a large, varied sample. J Pediatr 1990, I 1 7:298-307.

8. Strauss R, Dietz W: Effects of intrauterine growth retardation in premature infants on early childhood growth. J Pediatr 1997, I30(I):95-102.

9. Barros F, Huttly S, Victoria C, Kirkwood B, Vaughan J: Comparison of the causes and consequences of prematurity and intrauterine growth retardation: A longitudinal study in southern Brazil. Pediatrics 1992, 90(2):238-244.

10. Sung I, Vohr B, Oh W: Growth and neurodevelopmental outcome of very low birth weight infants with intrauterine growth retardation: Comparison with control subjects matched by birthweight and gestational age. J Pediatr 1993, 123:618-624.

II. Gutbrod T, Wolke D, Soehne B, Ohrt B, Riegel K: Effects of gestation and birth weight on the growth and development of very low birthweight small for gestational age infants: a matched group comparison. Arch Dis Child (Fetal Neonatal Ed) 2000, 82:F208-214.

12. Qvigstad E, Verloove-Vanhorick S, Ens-Dokkum M, Schreuder A, Veen S, Brand R, Oostdijk W, Ruys J: Prediction of height achievement at five years of age in children born very preterm or with very low birth weight: continuation of catch-up growth after two years of age. Acta Paediatr 1993, 82:444-448.

13. Rantakallio P: A I4 year follow-up of children with normal and abnormal birth weight for their gestational age. A popular study. Acta Paediatr Scand 1985, 74:62-69.

14. Saigal S, Stoskopf B, Burrows A, Rosenbaum P: Physical growth and current health status of extremely low weight infants and controls in adolescence (Abstract). Pediatrics 200I, 108:407-4I5.

15. Ericson A, Kallen B: Very low birthweight boys at the age of 19. Arch Dis Child (Fetal Neonatal Ed) 1998, 78:FI7I-FI74.

16. Peralta-Carcelen M, Jackson D, Goran M, Royal S, Mayo M, Nelson K: Growth of adolescents who were born at extremely low birth weight without major disability. J Pediatr 2000, 136:633-640.

17. Hirata T, Bosque E: When they grow up: The growth of extremely low birth weight $(1000 \mathrm{gm})$ infants at adolescence. J Pediatr 1998, 132:1033-1035.

18. Niklasson A, Engstrom E, Hard A, Albertsson-Wikland K, Hellstrom A: Growth in Very Preterm Children: A Longitudinal Study. Ped Res 2003, 54:1-7.

19. Hack M, Schluchter M, Cartar L, Rahman M, Cuttler L, Borawski E: Growth of Very Low Brith Weight Infants to Age 20 Years. Pediatrics 2003, I I 2:e30-e38.

20. Verloove-Vanhorick S, Verwey R, Brand R, Bennebroek Gravenhorst J, Keirse M, Ruys J: Neonatal mortality risk in relation to gestational age and birthweight: Results of a national survey of preterm and very-low-birthweight infants in the Netherlands. Lancet 1986, 1:55-57.

21. Fredriks A, Van Buuren S, Burgmeijer R, Meulmeester J, Beuker R, Brugman E, Roede M, Verloove-Vanhorick S, Wit J: Continuing positive secular growth change in the Netherlands 1955-1997. Pediatr Res 2000, 47:316-323.

22. Fredriks A, Van Buuren S, Hirasing R, Wit J, Verloove-Vanhorick S: Comparison of the Quetelet index (body mass index) in Dutch children in 1997 and 1980: new growth references for the detection of underweight, overweight and obesity. Ned Tijdschr Geneesk 200I, I 45: 1296-1303.

23. Roede M, Van Wieringen J: Growth diagrams 1980: Netherlands third nation-wide survey. Tijdschr Soc Gezondheidsz 1985, 63(suppl): I-34.

24. Kloosterman G: Over Intra-uteriene groei en de intra-uteriene groeicurve. Medschr v Kindergeneesk 1969, 37:209-225.

25. Kloosterman G: On intrauterine growth. Int J Gynaecol Obstet 1970, 8:895-9|2.

26. Ford G, Doyle L, Davis N, Callanan C: Very Low Birth Weight and growth into adolescence. Arch Pediatr Adolesc Med 2000, 154:778-784. 
27. Kok J, den Ouden L, Verloove-Vanhorick P, Brand R: Outcome of very preterm small for gestational age infants: the first nine years of life. BrJ Obstet Gynaecol 1998, 105:162-168.

28. Hokken-Koelega A, De Ridder M, Lemmen R, Den Hartog H, De Muinck Keizer-Schrama S, Drop S: Children born small for gestational age: Do they catch up? Pediatr Res 1995, 38:267-27|

29. Karlberg J, Albertsson-Wikland K: Growth in full-term small-forgestational-age infants: from birth to final height. Pediatr Res 1995, 38:733-739.

30. Fewtrell M, Cole T, Bishop N, Lucas A: Neonatal factors predicting childhood height in preterm infants: Evidence for a persisting effect of early metabolic bone disease? J Pediatr 2000, 137:668-673.

31. Albertsson-Wikland K, Boguszweski M, Karlberg J: Children born small-for-gestational age: postnatal growth and hormonal status. Horm Res 1998, 49:7-13.

32. Deal C: Polymorphisms and Mutations in the GH-IGF Axis in Very Short Children Born SGA due to IUGR, and the Implications for the Patients in Childhood and Adult life. Hormone Research 2003, 59(suppl I): I30.

33. Albertsson-Wikland $\mathrm{K}$, Wennergren $\mathrm{G}$, Wennergren $M$, Vilbergsson $\mathrm{G}$, Rosberg S: Longitudinal follow-up of growth in children born small for gestational age. Acta Paediatric 1993, 82:428-443.

34. Ibanez L, Potau N, Francois I, de Zegher F: Precocious Pubarche, Hyperinsulinism, and Ovarian Hyperandrogenism in Girls: Relation to reduced Fetal Growth. J Clin Endocrinol Metab 1998, 83:3558-3562.

35. Ibanez L, Potau N, Marcos M, de Zegher F: Exaggerated Adrenarche and Hyperinsulinism in adolescent Girls Born Small for Gestational Age. J Clin Endocrinol Metab 1999, 84:4739-474I.

36. Zegher de F, Albertssson-Wikland K, Wollmann H, Chatelain P, Chaussain J, Lofstrom A, Jonsson B, Rosenfeld R: Growth Hormone Treatment of Short Children Born Small for Gestational Age: Growth Responses with Continious and Discontinious Regimens over 6 Years. J Clin Endocrinol Metab 2000, 85:2816-282I.

37. Powls A, Botting N, Cooke R, Pilling D, Marlow N: Growth impairment in very low birthweight children at 12 years: correlation with perinatal and outcome variables. Arch Dis Child Fetal Neonatal Ed 1996, 75:FI52-FI57.

38. Hediger M, Overpeck M, McGlyn A, Kuczmarski R, Maurer K, Davis W: Growth and Fatness at three to six years of age of children born Small- or Large for Gestational Age. Pediatrics 1999, 104: I-6.

\section{Pre-publication history}

The pre-publication history for this paper can be accessed here:

http://www.biomedcentral.com/1471-2431/5/26/prepub

\section{Publish with Bio Med Central and every scientist can read your work free of charge}

"BioMed Central will be the most significant development for disseminating the results of biomedical research in our lifetime. "

Sir Paul Nurse, Cancer Research UK

Your research papers will be:

- available free of charge to the entire biomedical community

- peer reviewed and published immediately upon acceptance

- cited in PubMed and archived on PubMed Central

- yours - you keep the copyright 